IRA-International Journal of Management \& Social Sciences

ISSN 2455-2267; Vol.07, Issue 02 (2017)

Pg. no. 333-341

Institute of Research Advances

http://research-advances.org/index.php/RAJMSS

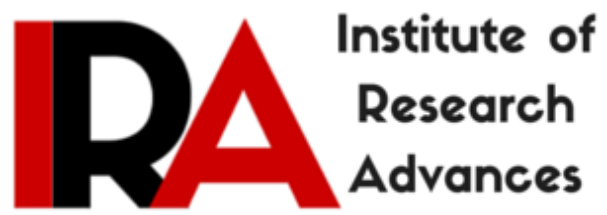

\title{
Protection of Children from Offences of Sexual Assault, Sexual Harassment and Pornography: A Law Enforcement View and Review
}

\author{
Vasuda Rao \\ BA.,LL.B., Student, SDM Law College, Centre for PG Studies \& Research in Law, \\ Mangaluru, Karnataka, India.
}

Type of Review: Peer Reviewed.

DOI: http://dx.doi.org/10.21013/jmss.v7.n2.p25

How to cite this paper:

Rao, V. (2017). Protection of Children from Offences of Sexual Assault, Sexual Harassment and Pornography: A Law Enforcement View and Review. IRA-International Journal of Management \& Social Sciences (ISSN 2455-2267), 7(2), 333-341. doi:http://dx.doi.org/10.21013/jmss.v7.n2.p25

(C) Institute of Research Advances

(cc) EY-NC

This work is licensed under a Creative Commons Attribution-Non Commercial 4.0 International License subject to proper citation to the publication source of the work.

Disclaimer: The scholarly papers as reviewed and published by the Institute of Research Advances (IRA) are the views and opinions of their respective authors and are not the views or opinions of the IRA. The IRA disclaims of any harm or loss caused due to the published content to any party. 


\section{ABSTRACT}

'Neutrality helps the oppressor, never the victim' is a famous quote of the Nobel laureate Elie Wisel. Although children have been maltreated in the course of our entire history, since they have no knowledge of the wrong and the right, hence 'interest theory' of jurisprudence remains true. ${ }^{l}$ Child abuse and neglect are serious global issues and can be physical, sexual or psychological. Many research studies have shown that children under the age group of 5-12 are at a higher risk of suffering from child abuse and neglect. The statistical analysis says that 40 million children become victims of child abuse all over the globe and 1,850 die due to extensive abuse and lack of affection and attention. An attempt has been made to differentiate the types of abuses and neglect, the signs and symptoms, the impact of the trauma on the well-being of the child. Drawing inferences from previous research works on the global issues, the paper has been prepared on the national context as the child sexual abuse is an under-reported offence in India. The study conducted by the Government of India in 2015 estimates the burden of sexual abuse which revealed shocking results and showed that every second child in the country was abused; among them, 52.94 per cent were boys and 47.06 per cent were girls. Highest sexual abuse was reported in Assam (52.27\%) followed by Delhi (41\%), Andhra Pradesh (33.87\%) and Bihar (33.27\%). ${ }^{2}$ There is a causal connection between child abuse and pornography; specifically child pornography depraves and corrupts the young minds which pose more danger to the child abuse. However, arguments frequently presented to defend pornography; such dichotomy stands between law and morality. The research paper tries to review the above issues focusing on recent legislations and views of policy makers in this regard.

\section{INTRODUCTION}

Children being a contributing factor to the population of a country, become an asset when they are nurtured and cared for. Unfortunately, they are subjected to a variety of hardships and torture physically, emotionally, psychologically and sexually. The paper deals with child sexual abuse and child pornography, the types, implication and the status of the legislations of India in this context. Although Child Sexual Abuse (CSA) and sexual harassment has been recently acknowledged as havoc in the global world, it is still a taboo in most of our societies. This has been aided by the lack of penal laws and stringent punishments in India. ${ }^{3}$

Many of the world wide institutions have tried to frame an all comprehensive definition of CSA. The most satisfactory definition is that of UNICEF.CSA means 'contacts or interactions between a child and an older or more knowledgeable child or adult (stranger, sibling, parent or caretaker) when the child is being used as an object of gratification for the older child's or adult's need. Such contacts or interactions are carried out against the child using force, trickery, bribes, and threats'. [UNICEF-2000] ${ }^{4}$

About $20 \%$ of women have been sexually abused in their childhood, worldwide. Discrimination in terms of sexual offences is still there with females outnumbering the male victims. In Japan $60 \%$ of women suffer sexual violence while $25 \%$ of women in India and 53-62\% of women in Bangladesh. It is shocking to know that the most of the reported sexual harassment cases turn out to be against the immediate close circle of the child, i.e. guardian, parent, teacher or caretaker. ${ }^{5} \mathrm{CSA}$ leaps to another dimension when the child is exploited for sexual stimulation by using a variety of media including photos, writing, recording

1Padmaja K., Child Interests- Socio Legal Perspectives, A Amicus books, First Edi., The ICFAI University Press, 2007, pp. 4-27

2 Tamuli RP Paul B Mahanta P. A statistical analysis of sexual assault-a retrospective study. J Punjab Acad Forensic Med Toxicol 2013;13(1):7-13

${ }^{3}$ Saritha Vashistha, Crime against Children, First Edi. , K.K. Publication, 2012, pp. 219-260

${ }^{4}$ Savitri Goonesekere, Children, Law and Justice- A South Asian Perspective, UNICEF, First Edi. Sage Publications India Pvt. Ltd. 2010, p. 10-88

${ }^{5} \mathrm{http}: / /$ www.indiastat.com, last visited on 01/03/2017 
film, videos etc. This is known as Child Pornography. Viewing Child Pornography increases the chances of an individual committing CSA and is found that internet child pornography offenders may be undetected molesters. It is illegal and a huge movement is working to globalize the criminalization of child pornography.

\section{DIFFERENT FORMS OF CSA}

The CSA not only includes physical touching, rape, sodomy, incest or penetration but also online sexual solicitation, obscene remarks, obscene calls, virtual sex and exhibitionism. According to The Protection of Children from Sexual Offences Act (POCSO)-2012, the various forms of Child Sexual Abuse are-

- Inserting any object or using any part of the body to cause penetration or making the child to do so

- Touching penis, vagina, breast, anus of a child with sexual intent

- Making physical contact to the child with sexual intent or making the child to do so

- Making any sound or gesture or exhibiting any object or part of body, with sexual intent so that it will be heard or seen by the child

- Constantly following or watching the child in any form with sexual intent or enticing child for pornographic purposes.

When the offence is committed by a trustworthy person like a member of the family, doctor or teacher and when a child is mentally challenged, the assault is termed to be 'grievous' and 'aggravated'. In this era of advanced technology, apart from the above mentioned forms, CSA happens online too. Since children as young as 7-8 to the teens have free access to the internet they receive solicitations through social media sites. Assaulters coaxing the child to wear revealing clothes, sex talking, sharing and showing pornography films, asking to take off the clothes to see the child nude, exposing intimate parts to the child, engaging children for cyber-sex scenarios are all forms of online sexual exploitation of the child.

\section{STATISTICS}

Reliable data analysis is hard to come across since the offence is hardly reported in India and the victims usually suffer in silence. However, things changed after Ministry of Women and Child Development conducted a National study and published the report - 'Study on Child Abuse: India 2007'. This study covered almost all the aspects of child abuse i.e. physical, psychological, sexual and child neglect in five categories namely children in a family environment, children in school, children at work, children on the street and children in institutions. This study was backed by the Indian Government covering about 13 Indian states and 1, 25,000 children. ${ }^{6}$

The results were shocking. 53.22\% of children reported being victims of sexual abuse. Among them 47.06\% were girls and 52.94\% were boys. Andhra Pradesh, Assam, Bihar and Delhi were the places with highest number of sexual assaults and sexual abuse among both the genders. 50\% of the abusers were known to the child and were trustworthy people and thus most of the children did not report the matter to anyone. ${ }^{7}$ They were scared, embarrassed or feared of being blamed. ${ }^{8}$ Children at work, in the streets and institutional care were more prone to be abused than the other two evidence groups. $73 \%$ of sexual abuse victims were in the age group of 11-18 years and this shows that teenagers were the most vulnerable. ${ }^{9}$

The National Crime Records Bureau (NCRB), in the year 2010 reported that 1721 rape and 2767

\footnotetext{
6http://www.indiastat.com, last visited on 01/03/2017

${ }^{7}$ Tamuli RP Paul B Mahanta P. A statistical analysis of sexual assault-a retrospective study. J Punjab Acad Forensic Med Toxicol 2013;13(1):7-13

${ }^{8} \mathrm{Geo}$ D' Silva, The voice of the Voiceless Children, CCF-India, First edi. Prajna, 2009, pp.75-77

${ }^{9}$ Supra note. 6
} 
kidnapping cases were registered in Assam which was $7.8 \%$ and $9.3 \%$ respectively of all the cases reported in India that year. Out of the1721 rape cases, 1204 (69.96\%) of the cases' offender was a known person to the victim. ${ }^{10}$

Child Sexual Abuse also includes the abuses and assaults that happen online. With children gaining free and easy access to the internet, their innocence coupled with their trusting nature puts them into a very dangerous position with child molesters and traffickers who befriend children on social media sites. Use of internet has both national and international implications which make monitoring and policing the activities of online child abusers all the more difficult. ${ }^{11}$

The offender uses social sites to befriend the child, gain its trust and grooming it for later abuse or for child pornography or for the much worse-trafficking and prostitution.

Although small scales of studies have been carried out, it is hard to paint an overall picture as they either focus on a small geographical area or they do not include all the forms of abuses that happen online. According to a study conducted by a popular national magazine, 'The Hindu' in 2013, there is a 100\% increase in cases of transmission and uploads of child pornography when compared to the previous year. Uttar Pradesh stands first with the arrests (167) and Maharashtra second (130) regarding offences related to Child Pornography.

Corporal punishments, use of children for creation of pornography, exposure are all not reflected in NCRB as they are not offences under Indian Penal Code. India has been a signatory on two optional protocols to UN Conventions on the Rights of Child dealing with involvement of child in armed conflicts, sale of children, child pornography and prostitution.

\section{SIGNS AND SYMPTOMS}

Identifying and reporting the offence of abuse on children is a very difficult task. It is partially because the victimized child does not realize that he is being harassed and sometimes because the child either feels embarrassed, fearful or guilty. Even after the initial stage of suspecting, it is very hard to substantiate this without obtaining any solid evidence. ${ }^{12}$

However, the victims of CSA and the offenders show particular traits. The victims may

- Avoid or maintain distance from certain people, seem frightened of a certain person in the family or friend circle.

- Have physical symptoms like anal or vaginal soreness, bleeding in the genital area, bed wetting, recurring pain during urination, unexplained bruises, sexually transmitted diseases and in the worst cases, pregnancy.

- Exhibit sexual behavior or knowledge which one wouldn't expect a child to know for his/her age.

- Abuse another child sexually

- Undergo changes in behavior, have mood swings, sudden decline in the performance at school, abstain from going to school, reluctance to leave after school hours as if he/she does not want to go home.

- Attempts at suicide or running away in the extreme cases

- Spend much more or much less time online ,texting, gaming or on social media sites

- Become withdrawn or outraged after using the internet

\footnotetext{
${ }^{10} \mathrm{https}$ ///victimsofcrime.org, last visited on 04/03/2017
}

${ }^{11}$ www.childlineindia.org.in, last visited on $07 / 03.2017$

${ }^{12}$ Asha Bajpai, Child Rights in India, Law, Policy and Practice, 2nd Edi. Oxford University Press., 2011, pp.22-29 
- Become very secretive about their activities on their phones or computers

Along with the child, the offenders also show some traits. When one clearly watches the relationship pattern between the offender and the victim, there are a few signs that appear repeatedly or in combination. The offender and the victim may rarely touch or look at each other, consider their relationship with each other to be entirely negative and state that they do not like each other. More than often, the child abusers also have had a past of someone else abusing them in their childhood. The abusers themselves are usually the victims of various substances like alcohol, drugs, etc. And parents, who abuse their spouses, also tend to abuse their children. The online abusers have admitted being frequent users of child pornography.

\section{IMPLICATIONS}

The trauma of the abuse on the victim is devastating. Sometimes this becomes a severe blow to the individual's personality. Though CSA can ruin their childhood, the impact can last a lifetime. There are both short term and long term effects. But, every child and every situation is different. Thus, it is not possible to give a universal and all comprehensive data about the implications. Apart from the physical signs of the abuse, it is the psychological or the emotional effects that can cause more harm in the long term. ${ }^{13}$

A few of the common consequences of CSA are-

- Short term effects include bed wetting, thumb sucking, sleep disturbances, eating problems, bad performance at schools and unwillingness to participate in other school or social activities.

- If they had suffered abuse as a child, it is more likely that they suffer abuse again and is known as re-victimization.

- Emotional challenges like low self-esteem, anxiety, guilt, self-blame, anger, etc.

- Become addicted to drugs, alcohol and other substances.

- Mental health problems like depression, self-harm, post-traumatic stress disorder, suicidal thoughts etc.

- Struggles with relationships.

- Learning difficulties, lack of concentration and they may feel powerless.

- They may feel betrayed and anger on the adults and social system which failed to protect them.

- Traumatic sexualisation- the child's sexuality is distorted with the age inappropriate sexualisation.

- $\quad$ The child may try to feel 'powerful' by abusing another child.

- The child may become isolated from the entire society and remain aloof.

There is a very close relationship between child pornography and the sexual abuse of the children. ${ }^{14}$ Using children for producing pornographic films is another form of abuse that is sky-rocketing nowadays. This is equally harmful not only to that child but also to the children all over the globe. This content, once uploaded to the internet can be accessed from anywhere around the globe and thus pave way to sexually stimulate the offender in preparation for offending. ${ }^{15}$ This victimization never ends because these images, videos can never be fully erased and it can be passed to and fro many times. The victims can never rest in peace knowing that any other person might have their video, image etc. This could affect the child's future too i.e. its career, relationships and other phases of life. There shall be no privacy. This child pornography may desensitize children and normalize sexual activity among them.

\footnotetext{
${ }^{13}$ https://victimsofcrime.org, last visited on 07/03/2017

${ }^{14}$ Saritha Vashistha, Crime against Children, First Edi. , K.K. Publication, 2012, pp. 219-260, pp.79-96

${ }^{15}$ Tripathi S C. and Vibha Aroora, Law relating to Women and Children, Forth Edi. Central Law Publications, 2015, pp.34-66
} 
These are some of the consequences and it is to be kept in mind that every child is different and thus their coping mechanisms are different. Some children recover quickly and bounce back to life with the entire trauma left behind. The environments at home, schools and the peer groups play a significant factor in buffering the impact. Even the norms of that State become a contributing factor in the protection of the children.

\section{LEGISLATIONS IN INDIA}

Since more than half of the population of children in India was abused, a need to check this disaster was strongly felt among the policy makers. Protection and Prosecution play an important part in the life of a child where protection is the job of the parent and prosecution is the job of the State.

Keeping this in mind, the Parliament of India has passed a Bill on 'Protection of Children from Sexual Offences Act 2012'. Before this Act was passed, Goa Children's Act, 2003, was the only specific piece of child abuse legislation and Child Sexual Abuse was prosecuted under the following sections of IPC-

- $\quad$ I.P.C (1860) 375- Rape

- $\quad$ I.P.C (1860) 376- Punishment for Rape

- I.P.C (1860) 377- Unnatural offences and is generally invoked when boys suffer sexual abuse

- $\quad$ I.P.C (1860) 354-Outraging the modesty of a woman

- I.P.C (1860) 509-For insulting the modesty of a woman

- Obscenity and Pornography were dealt under the Young Persons (Harmful Publications) Act, 1956

- $\quad$ Publication and transmission of pornography through the internet is an offence under section 67 of the Information Technology Act,2000

But these laws were deemed to be inadequate and possessed certain loopholes. IPC section 375 does not include male victims and the term 'penetration' is restrictively interpreted. The same holds good for IPC section 376. Forced sexual intercourse with boys is not included under section 377. IPC section 354 lacks a statutory definition of 'modesty' and does not include the male child. There a few controversial cases of CSA that were reported across the country. ${ }^{16}$

\section{PROMINENT CASES (BEFORE POCSO ACT)}

Bharwada Bhoginbhai Hirjibhai v. State of Gujarat ${ }^{17}$

The accused, a middle aged man had confined 2 of his daughter's friends aged 10, who had come to his home to meet his daughter and raped them. The trial court convicted him under section 376, 354 and 340 of IPC. The High Court, upheld the conviction while reducing the charge from rape to attempt to rape. The Supreme Court upheld the judgment of the trial court on the ground that minor discrepancies in the evidence were not relevant. This judgment was relied on in later judgments to secure justice by convicting the accused when there were no eye witnesses to support evidence given by the victim.

Sakshi v. Union of India ${ }^{18}$

The NGO Sakshi filed a PIL (Public Interest Litigation) to broaden the definition of rape of children where the child is abused by insertion of objects into the vagina or insertion of the male organs into anus or mouth. The Supreme Court rejected the plea and dismissed the PIL. However it issued valuable guidelines for trial of rape and abuse that involves children. These are called as Sakshi guidelines. A screen or some sort of barrier that reduces the visibility of the face or body of the accused to the victim, the victims being able to take breaks in between as and when required are a few of the guidelines.

\footnotetext{
${ }^{16}$ The Protection of Children from Sexual Offences Act,2012

${ }^{17}$ (1983) 3 SCC 217 : 1983 SCC (Cri) 728 : AIR 1983 SC 753

${ }^{18}$ AIR 2004 SC 3566
} 
Anchorage Case C $^{19}$

A charity worker and UK citizen set up an Anchorage shelter in Mumbai. There was another UK citizen who was a frequent visitor to the home. The pair was charged with sexual assault after 5 boys filed a complaint against them with the nearby police station. They were acquitted by the Mumbai High Court for lack of evidence. But the Supreme Court upheld the guilty verdicts of the trail court and sentenced the men to six years.

\section{PROTECTION OF CHILDREN FROM SEXUAL OFFENCES ACT (POCSO), 2012}

These laws were enacted as a part of child protection policies. The Parliament of India passed the 'Protection of Child from Sexual Offences Bill, 2011' regarding CSA on May 22, 2012 into Act. This step is a milestone in the arena of protecting the children and it covers all the loopholes in the previous laws. A few of its salient features are-

- It establishes the jurisdiction to certain Special Courts for trial of the offences specified under this Act.

- The child's right to privacy and confidentiality is protected and respected in all the stages of the judicial proceedings involving the child.

- It defines the term 'child' as any person below the age of eighteen years.

- The term 'Aggravated penetrative sexual assault' is broadly defined and the punishment for the same would be imprisonment not less than ten years, which may extend to imprisonment for life and liable to pay fine.

- Sexual assault without penetration attracts imprisonment not less than three years, which may extend to five years and liable to pay fine.

- Any question which involves sexual intent, without physically touching the child but exposing the child to pornography, following or watching the child constantly, forcing the child to exhibit his/her body parts were all classified under sexual harassment.

- This Act specifically deals with the offenders under Child Pornography, with various abettors and offenders being granted various severities of imprisonments and fine or both.

- The offence need not be reported by the victims themselves, i.e. any person who has an apprehension that an offence under this Act is likely to be committed can file a report.

- Special procedures are followed while recording the statements of the child.

- This Act makes it compulsory to report the offence.

- The defense cannot ask any aggressive question to the child and instead, the questions are routed through the judge to the child.

- The minor should not be exposed to the accused in any way during the recording of the evidence.

\section{PROMINENT CASES (AFTER POCSO ACT)}

State of Mahrashtra v. Dattatraya ${ }^{20}$

The accused was the neighbor of the victim, aged five years and he had taken the victim to his house and forcibly and had vaginal and anal sex, caused her cranial injuries and smothered her as a result of which she died. The accused was found guilty under POCSO and was awarded the capital punishment.

State v. Mohd. Zahid ${ }^{21}$

The accused caught hold of the victims hand forcefully, after her school hours, near a tea shop and asked

\footnotetext{
${ }^{19} \mathrm{http}: / /$ lawmantra.co.in/the-anchorage-case-2011-landmark-judgment-on-child-abuse/last visited on 05/03/2017

${ }^{20} 2007$ LLR 1132 (SC) 132

${ }^{21}$ SLP(Crl) No. 2623 of 2015
} 
her to accompany him and the victim tried to free herself due to which the victim suffered injuries on her right hand. Since she immediately got rid of herself from the crutches of the accused, this shows that the touch was against her wishes and it was intentional. The Supreme Court convicted the accused to be guilty under POCSO Act and was punished under section 8 and 12 of POCSO Act for sexual assault and sexual harassment.

State v. Mohan, $2015^{22}$

The accused in this case had attempted to commit rape upon a minor girl child aged about eleven and the Supreme Court emphasized the fact that 'the act of the convict, though on the face of it is not gruesome, but has had farfetched and irreparable consequences on the life of a minor girlchild'. There was no leniency in this matter and the accused was convicted under the POCSO Act (section 6 and section 18) and the act was termed to be 'aggregated penetrative sexual assault'.

\section{CONCLUSION}

Child Sexual Abuse is veiled in secrecy. Most of the cases of CSA go unnoticed and unreported due to the callousness of the parents and guardians, innocence of the children, embarrassment and the social stigma attached to it, the insensitivity of the investigating officers and the lack of implementation of the existing laws. It is not only the duty of the State to pass certain legislations for the protection of the children, but also the duty of every responsible citizen to behave accordingly. The famous saying in India states that home is the first school and mother is the first mentor. It becomes the duty of the care taker of the child to educate them about the nature of people, differences between the good and the bad 'touch' and to protect themselves from various types of abuses. It is necessary to create a protective environment around the child as they are the prized possessions of a country.

It is very vital for the social progress that the children are healthy, educated, loved, happy and have ample of opportunities to shine. It is our duty that child abuse and neglect is combated as early as possible because the children of today are the leaders of tomorrow.

\section{REFERRENCES}

- Gurudath CA., Women Child Law and Society, A volume of Collection of Essays, March, 2006

- Paras Diwan \& Peeyushi Diwan, Human Rights and The Law, Universal and Indian, Deep \& Deep Publications, 1996

- Malik and Raval, Law \& Social transformation in India, $3^{\text {rd }}$ Edi. Allahabad Law Agency, 2011

- Saritha Vashistha, Crime against Children, First Edi. , K.K. Publication, 2012

- Padmaja K., Child Interests- Socio Legal Perspectives, A Amicus books, First Edi., The ICFAI University Press, 2007

- Geo D' Silva, The voice of the Voiceless Children, CCF-India, First edi. Prajna, 2009

- Savitri Goonesekere, Children, Law and Justice- A South Asian Perspective, UNICEF, First Edi. Sage Publications India Pvt. Ltd. 1998.

- Anjani Kant, Law relating Women and Children, First Edi. Central Law Publications, 2003

- Tripathi S C. and Vibha Aroora, Law relating to Women and Children, First Edi. Central Law Publications, 2004

- Sujatha D., Child Protection- Changing Dimensions., First Edi. The ICFAI, 2008

- Asha Bajpai, Child Rights in India, Law, Policy and Practice, $2^{\text {nd }}$ Edi. Oxford University Press., 2011

- Tamuli RP Paul B Mahanta P. A statistical analysis of sexual assault-a retrospective study. $J$ Punjab Acad Forensic Med Toxicol 2013;13(1):7-13

- Alok Kumar, The problem of Child Sexual Abuse in India Laws, Legal Lacuna and the Bill-

${ }^{22}$ Criminal Appeal No. 878-879 of 2011 
PCSOB-2011. J Punjab Acad Forensic Med

- The Protection of Children from Sexual Offences Act,2012

- https://indiankanoon.org

- www.the-laws.com

- www.childlineindia.org.in

- https://medscape.com

- www.soc.ucsb.edu

- www.childhealth-explanation.com

- https://www.rainn.org

- https://www.nspcc.org.uk

- https://victimsofcrime.org

- www.thehindu.com 